\title{
食品含油廃水処理を目的とした粗レシチン/ 水エマルションの濾過特性の検討
}

\author{
川勝孝博* ・ 中島雅達** ・市川創作 ${ }^{* * *}$-鍋谷浩志**** 中嶋光敏****
}

\author{
Study on Filtration Characteristics of Crude Lecithin/Water \\ Emulsion for Food Oily Waste Water Treatment
}

\author{
Takahiro KaWAKatsu*, Masamichi NaKAJIMA ${ }^{* *}$, Sousaku ICHIKAWA ${ }^{* * *}$, \\ Hiroshi NABETANI ${ }^{* * * *}$ and Mitsutoshi NAKAJIMA ${ }^{* * * *}$ \\ * The Graduate School of Engineering, Tohoku University, Aramaki Aza Aoba \\ 07, Aoba-ku, Sendaishi, Miyagi 980-8579 \\ ** Department of Development, Kyowa Kako Co., Ltd., Nishigotanda \\ 7-25-19, Shinagawa-ku, Tokyo 141-0031 \\ *** Institute of Applied Biochemistry, University of Tsukuba, Tennodai \\ 1-1-1, Tshukuba-shi, Ibaraki 305-8572 \\ ${ }^{* * * *}$ National Food Research Institute, Ministry of Agriculture, Forestry and Fisheries, \\ Kannondai 2-1-2, Tsukuba-shi, Ibaraki 305-8642
}

\begin{abstract}
As for oily waste water treatment in food industries, the membrane technology has a large potential to reduce the operation time, equipment space and total costs. Using crude lecithin/water emulsion as a model of oily waste water, filtration characteristics on the flux and total organic carbon (TOC) rejection were investigated with a wide range of membranes in reverse osmosis, nanofiltration, ultrafiltration, and microfiltration. Constant flux and TOC rejection were obtained in crossflow filtration with hydrophilic membranes having smaller pores than the emulsion droplets $(1 \sim 2 \mu \mathrm{m})$. Free phospholipids were removed with reverse osmosis membranes or nanofiltration membranes having high $\mathrm{NaCl}$ rejection abilities. When microfiltration membranes having larger pores than the emulsion droplets were used, the membrane characteristics such as the pore structure and hydrophobicity largely affected the filtration characteristics : asymmetric membranes gave relatively high fluxes when its loose side was used against the feed emulsion as a depth filter, symmetric membranes having a spongoid pore structure and a pore size similar to the emulsion droplets brought about almost 0 flux owing to an extreme progress of pore blocking, hydrophobic membranes of adequate pore sizes showed a possibility to result in the negative TOC rejection.
\end{abstract}

(Received, Jul. 6, 1998 ; Accepted, Dec. 28, 1998)

地球環境への負荷の低減が叫ばれる中, 廃水処理に要 求される水準がますます高まってきており，例えば，廃 水中の重油類の含有量は $5 \mathrm{ppm}$, 動植物油脂類の含有量
は $30 \mathrm{ppm}$ 以下に規制されている1). 従来から，含油廃水 の処理には生物処理法や曝気法が用いられているが, 省 スペース化, コスト削減, 水質の改善, あるいは処理速

* 東北大学大学院工学研究科（广980-8579 宮城県仙台市青葉区荒巻字青葉 07）

** 共和化工株式会社（テ141-0031 東京都品川区西五反田 7-25-19）

*** 筑波大学底用生物化学系（干 305-8572 茨城県つくば市天王台 1-1-1）

*****農林水産省食品総合研究所（厂305-8642 茨城県つくば市観音台 2-1-2） 
度の向上を目的として, 膜分離法の適用が検討されはじ めている2).これまでに，精密滤過膜を用いた研究とし て, 半導体のアルカリ洗浄水加らの油分の除去（セラ ミック膜 $)^{3)}$, アルキルベンゼンプラント廃水からの芳香 族やパラフィンの除去 (セラミック膜) ナトリゥム (SDS) で水中に分散させた灯油の除去（回 転型セラミック膜) ${ }^{5)}$, 水中に分散させたドデカンの除去 (高分子膜とセラミック膜) ${ }^{6)}$ などが挙げられる。 また, 限外滤過膜を用いた研究としては, 切削油（高分子膜, 䨘拌セル) ${ }^{7)}$, 切削油 (高分子膜, 流通式平膜セル) ${ }^{8)}, 1$ ラニアン粗製油 (管状のセラミック膜) ${ }^{9)}$ を水中に分散 させて除去を行ったあのが報告されている。一般的に， 含油排水は $\mathrm{O} / \mathrm{W}$ (oil in water) エマルションの状態に なっており, 分散している油滴は液体であるが, 多孔質 ガラス精密滤過膜を用いた油滴の分画実験 ${ }^{10) 11}$ や，シリ コンマイクロチャネルを用いた滤過現象の顕微鏡観察 ${ }^{12)}$ などから，固体粒子に近い挙動を示すと考えられる．膜 分離法は阻止対象とする粒子・物質のサイズの違いによ り, 逆浸透法, ナノ滤過法, 限外滤過法, および精密滤 過法に分類されるが，これらの膜で含油廃水を処理した 場合の滤過特性に関する系統的な研究はほとんどなされ ておらず, また, 食品産業関連の含油廃水の膜処理につ いて検討を行った報告も少ない，例えぱ，大豆油を精製 する際の脱ガム工程では, 油に水や水蒸気を接触させて 水相側にレシチンや樹脂状物質を抽出して除いている. 水相中の主成分はレシチンであり, 油(トリグリセリド) も $\mathrm{O} / \mathrm{W}$ エマルションの状態で存在する ${ }^{13)}$.レシチンは,
食品用乳化剂として有用であり，含レシチン廃水からあ 精製されているが，多くのエネルギーを必要とする減圧 加熱法が用いられている13)，現状では，含レシチン廃水 のほとんどは脱脂大豆かすに再吸収させて飼料にするな どの方法で処分されている 廃水を省エネルギー的に処理し，レシチンの濃縮も可能 な膜処理の適用可能性を検討することは意義深いと云え 万.

そこで本研究では, 逆浸透膜, ナ/湑過膜, 限外滤過 膜, および精密滤過膜といった種々の細孔径, 構造, 材 質の異なる膜を用いて, 粗レシチン（トリグリセリド,

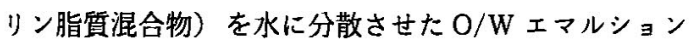
を滤過処理した際の透過流束や油分の阻止率などの滤過 特性に関する検討を行った，また，柾水性の精密港過膜 を用いて，O/W エマルションの油滴を膜内に蓄積させ,

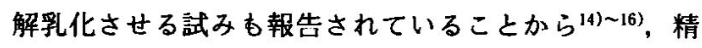
密澽過膜に関しては膜の親疎水性の影響についても検討 を行った.

\section{実 験 方 法}

\section{1. 供試材料}

(1) 粗レシチン/水エマルション

粗レシチン(リン脂質 60〜70\%,トリグリセリド 27〜 $37 \%$ 混合物）として和光純薬製の大豆レシチン（Lecithin, from Soybean) を用いた. 水 10 にに粗レシチンを 4.6 wt \% 加え，図 1 に示す(株)日本精機製作所製の装置 を用いて, 一晚, 弱撸拌して予備乳化を行った. その後,

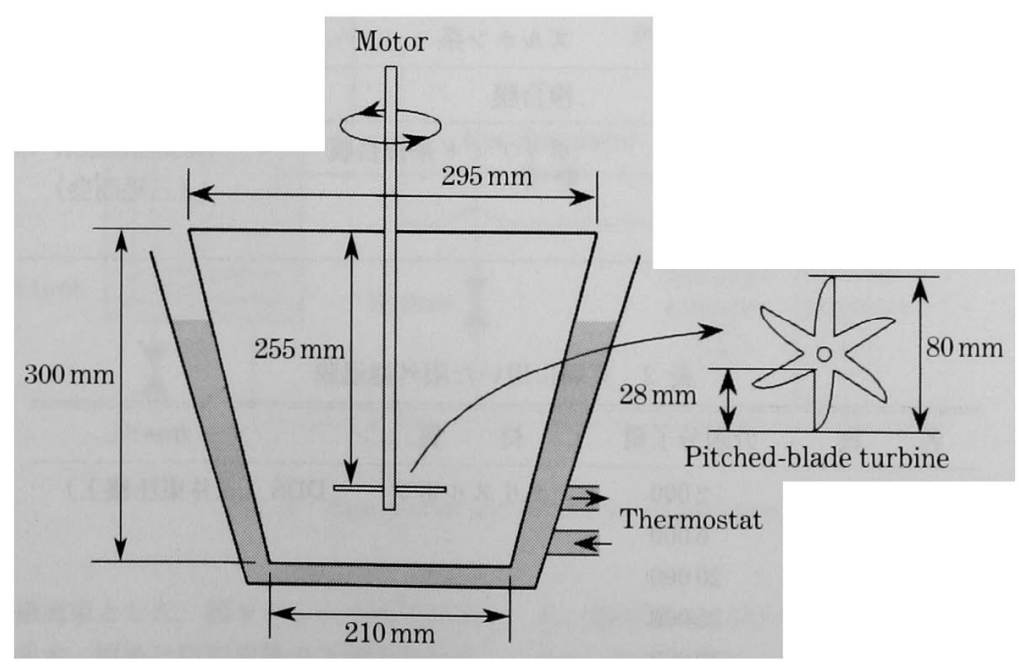

Fig. 1 Apparatus for emulsification 
同じ装置を用いて，水温 $25^{\circ} \mathrm{C}$ ，約 $7300 \mathrm{ppm}$ で 20 分間 筧拌するここで, 含油廃水モテル原液として粗レシチ ン/水エマルションを調製した．この時の原液の $\mathrm{pH}$ は 6.3であった. エマルションの顕微鏡観察を行ったとこ

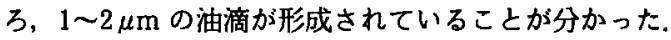
今回の条件では, レシチン濃度 $4.6 \mathrm{wt} \%$ が, 分相せずに エマルションの作製が可能な上限であった．阻止率を求 めるため，原液と透過液の全有機炭素（TOC）を島津製 作所の TOC-5000で湘定した. 原液エマルションの TOC 值は, 約 $10000 \mathrm{ppm}$ であった.

\section{(2) 膜}

使用した逆浸透膜およびナノ清過膜を表 1 ，限外滤過 膜を表 2 にそれぞれ示す．膜の絰密さを，逆浸透膜とナ ノ滤過膜の場合は $\mathrm{NaCl}$ の阻止率，限外滤過膜の場合は 分画分子量で表している. 使用した精密滤過膜を表 3 に 示す. 精密滤過膜の場合は, 細孔径以外に, 細孔構造, 親柾水性の違いが透過流束や TOC 阻止率におよばす影 響を検討する. 酢酸セルロース (CA) 非対称膜は, デブ スフィルターであり, 粗な面 (LS) と密な面 (TS) のど ちらを原液側に用いるかによって，減過特性が異なるこ とが予測される(17)18)。セルロース混合エステル (CE) 膜
とポリビニリデンフロライド (PVdF) 膜はスポンジ状 の細孔を持つ対称膜である. ポリテトラフルオロエチレ ン (PTFE) 膜は, 延伸によって細孔が形成されるため細 長い形状の細孔を持つ。一般的には疎水性であるが，親 水化処理したものあ市販されており，細孔構造が同じ親 水性膜として比較のため使用した. ポリカーボネート （PC）膜は, トラックエッチング処理膜であり，均一な 直円筒状の細孔を持つ膜である.

\section{2. 滤過実験装置}

図 2 に東レ(株)製の滤過実験装置を示す．膜モジュー ルは 3 連になっており，クロスフロー滤過方式で異なる 3 種の膜を同時に試験することが可能である. その際, 膜の下側を原液が流れ，膜の上部から透過液を回収す る. 流量や操作圧力の調節はバイパスと各バルプの開閉 で行う．今回は, 原液量を $10 l$ として, 原液浱度が一定 となるように透過液を原液に戻す全循環方式で実験を 行った. 温度は $25^{\circ} \mathrm{C}$, 原液流量は $3 l \cdot \mathrm{min}^{-1}$ とした. 操

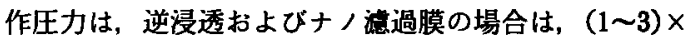
$10^{6} \mathrm{~Pa}$ ，限外滤過膜の場合は，(2〜6) $\times 10^{5} \mathrm{~Pa}$ ，精密滤過 膜の場合は， $5 \times 10^{4} \mathrm{~Pa}$ とした. 300 分間運転を行うこと によって，透過流束はほぼ定常に達したため，この時の

表 1 実験に用いた逆浸透膜およびナノ涜過膜

\begin{tabular}{|c|c|c|c|}
\hline 名 称 & $\mathrm{NaCl}$ 阻止率 [\%] & 材 & $x ー カ ー$ \\
\hline $\mathrm{ES}-10$ & 99.5 & ポリアミド系複合膜 & 日東電工 \\
\hline NTR-7250 & 60 & ポリビニルアルコール系 & \\
\hline NTR-7450 & 50 & スルホン化ポリエーテル & \\
\hline NTR-7430 & 30 & スルホン系 & \\
\hline HR-98 & 98 & 複合膜 & DDS（三井東圧機工） \\
\hline G 5 & 65 & ポリアミド系複合膜 & Desalination \\
\hline G 10 & 30 & & （三晃商会） \\
\hline G 20 & 10 & & \\
\hline
\end{tabular}

表 2 実験に用いた限外減過膜

\begin{tabular}{|c|c|c|c|}
\hline 名 & 分画分子量 & 質 & メーカー \\
\hline GR-90 pp & 2000 & ポリスルホン & DDS（三井東圧機工） \\
\hline GR-81 pp & 6000 & & \\
\hline GR-61 pp & 20000 & & \\
\hline $\mathrm{GR}-60 \mathrm{pp}$ & 25000 & & \\
\hline GR-51 pp & 50000 & & \\
\hline GR-40 pp & 100000 & & \\
\hline
\end{tabular}


表 3 実験に用いた精密港過膜

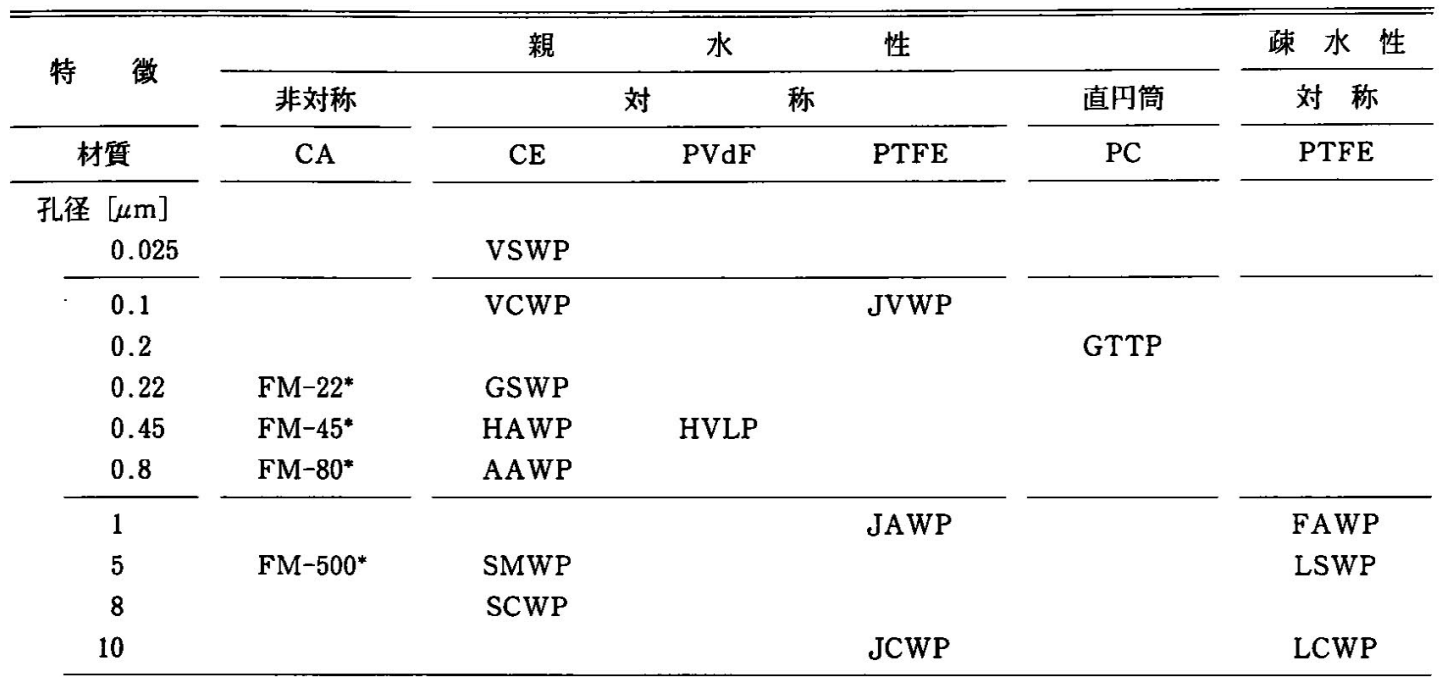

$\mathrm{CA}$ : 酢酸セルロース, CE：セルロース混合エステル, PVdF : ポリビニリデンフロライド, PTFE : ポリテトラ フッ化エチレン, PC : ポリカーボネート

*富士写真フィルム社製, その他の膜は Millipore 社製

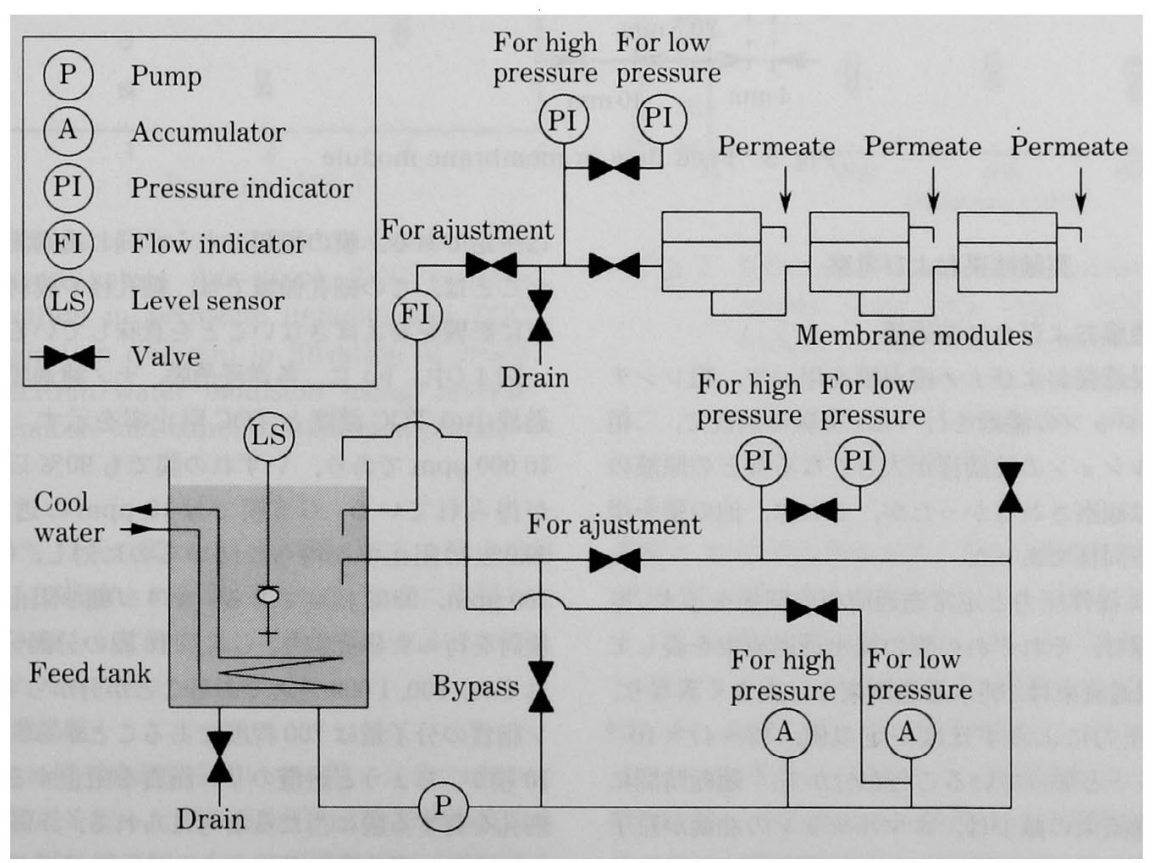

Fig. 2 Apparatus for filtration experiment

透過流束を定常透過流束とした．膜モジュール内での原 液の流れを図 3 に示す．原液は円形平膜の下側中央から 流入し，外周部に向かって広がるように流れて流出す
る. 膜面稙は $0.003 \mathrm{~m}^{2}$, 流路長さ（有効膜面の半径） 32 $\mathrm{mm}$, 平均流路幅（有効膜面の外周の 1/2) $100 \mathrm{~mm}$, 流 路高さ $1.45 \mathrm{~mm}$ である. 


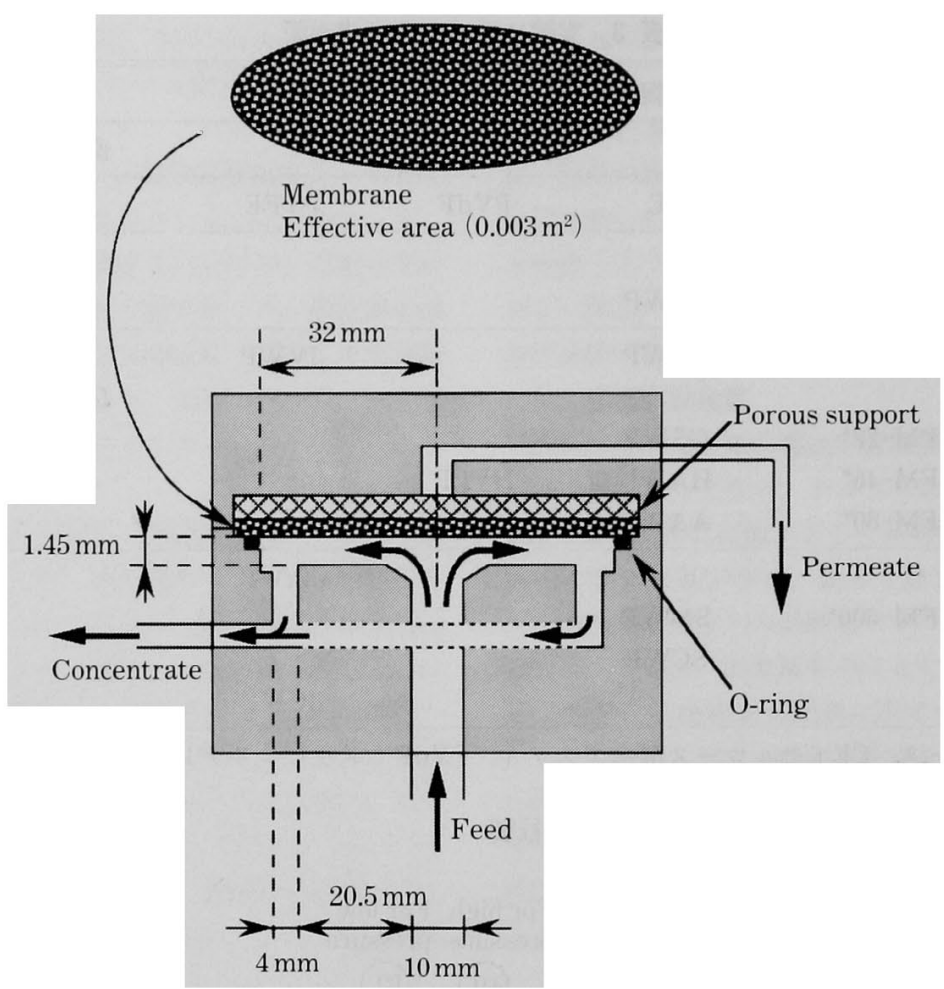

Fig. 3 Feed flow in membrane module

\section{実験結果および考察}

\section{1、逆浸透膜およびナノ滤過膜}

まず，逆浸透膜およびナノ滤過膜を用いて，粗レシチ ン/水エマルションの滤過を行った. 実験の前後で, 二相 分離やエマルションの油滴径が大きくなるなどの原液の 解乳化現象は観察されなかったが，これは，他の膜を用 いた実驗でも同様であった。

図 4 (上) に操作圧力之定常透過流束の関係を示す. 原 点を通る直線は，それぞれの膜の純水透過流束を表して いる. 定常滤過流束は, 純水透過流束とは大きく異なり, 膜の種類や圧力によらずほぼ一定の值, $(2 \sim 4) \times 10^{-6}$ $\mathrm{m}^{3} \cdot \mathrm{m}^{-2} \cdot \mathrm{S}^{-1}$ となっていることが分かる．運転時間に ともなう透過流束の減少は, エマルションの油滴が粒子 として機能し，膜面で抵抗（ケーク）層を形成している ことが原因と考えられる。クロスフロー法過では，一般 的に，透過液の流れによって膜面に運ばれる油滴の量 が，原液の流れによってかき取られる量とバランスする まで透過流束が咸少する ${ }^{19)}$ ，今回の実験では，原液流量 を $3 l \cdot \mathrm{min}^{-1}$ と固定しているため, 油滴のかき取り量
は一定である，膜の種類によらず同じ透過流束が得られ たことは，この細孔領域では，細孔径や膜材質は透過流 束に影響をおよぼさないことを意味している。

図 4 (中, 下) に, 各逆浸透膜, ナノ滤過膜にお污透 過液中の TOC 濃度と TOC 阻止率を示す．原液濃度は $10000 \mathrm{ppm}$ であり，いずれの膜でも $90 \%$ 以上の阻止率 が得られている. G 5 膜では $10 \mathrm{ppm}$ の透過液濃度, 99.9\% の阻止率が得られているのに対 L, G 10 膜では $700 \mathrm{ppm}, 93 \%$ 程度である. オリコ糖の阻止率について 検討を行った研究より，G 5, G 10 膜の分画分子量は，そ れぞれ, 600, 1000 付近であることが分かっている20).リ ン脂質の分子量は 700 程度であることから， G5 膜と G 10 膜が, ちょうど遊離のリン脂質を阻止する境界領域の 細孔を有する膜に当たると考えられる.トリグリセリド の主成分と考えられるトリオレインの分子量す 900 弱で あるが，その大部分はリン脂質に囲まれ，ょり大きな油 滴の状態で存在していると考えられる.すなわち, 油滴 の形成に使われているトリグリセリドやリン脂質は阻止 されていると考えられる. リン脂質がミセルを形成して いる可能性については次の限外滤過膜で議論する. 塩の 


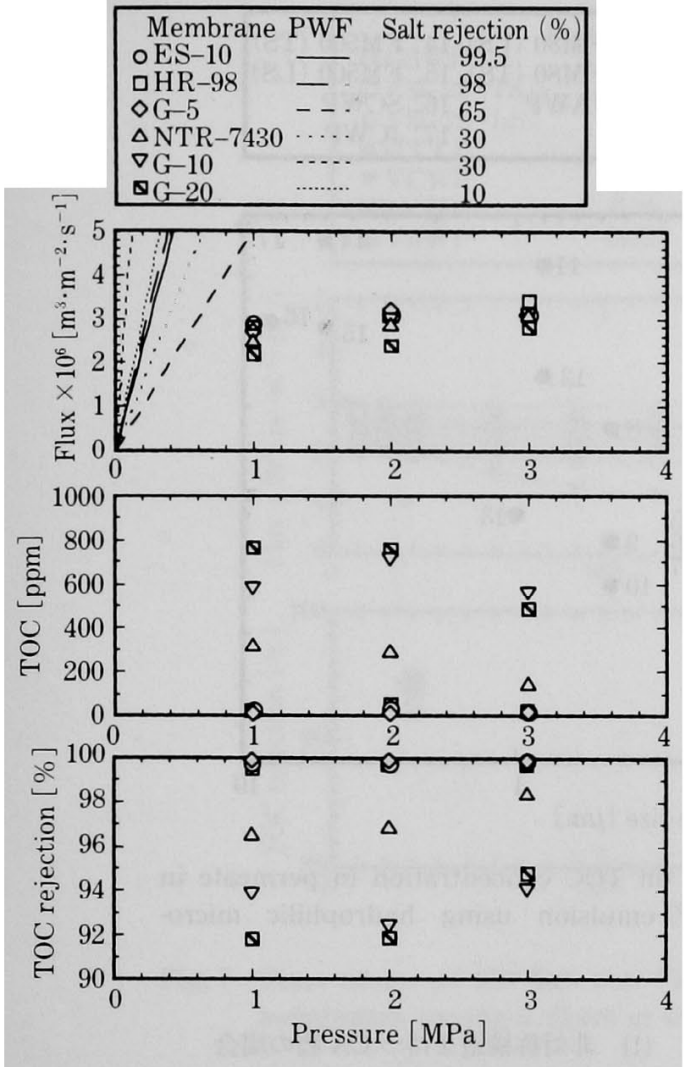

Fig. 4 Effects of the operating pressure on the steady state flux (top), TOC concentration in permeate (middle) and TOC rejection (bottom) in filtration of crude lecithin/water emulsion using reverse osmosis and nanofiltration membranes

阻止率が 30\% 以下の膜で，在力が高くなると阻止率が 高くなる傾向か観察されたが，これは，膜面に堆積した 油滴首が二次膜として機能し，圧力が高くなるほど厚く 緻密になったためと考えられる。

\section{2. 限外满過膜}

図 5 （上）に限外法過膜を用いて, 粗レシチン/水エマ

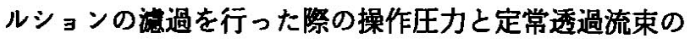
関係を示す. 限外滤過膜でも, 逆浸透膜やナ/滤過膜と 同等の定常透過流東加得られている，逆浸透膜やナ/滤 過膜を用いた実験と同様の機構で, 油滴の堆積とかき取 りがバランスしたところで透過流束が定常に達したあの と推察される.

図 5 （中，下）に限外湢過膜における透過液中の TOC

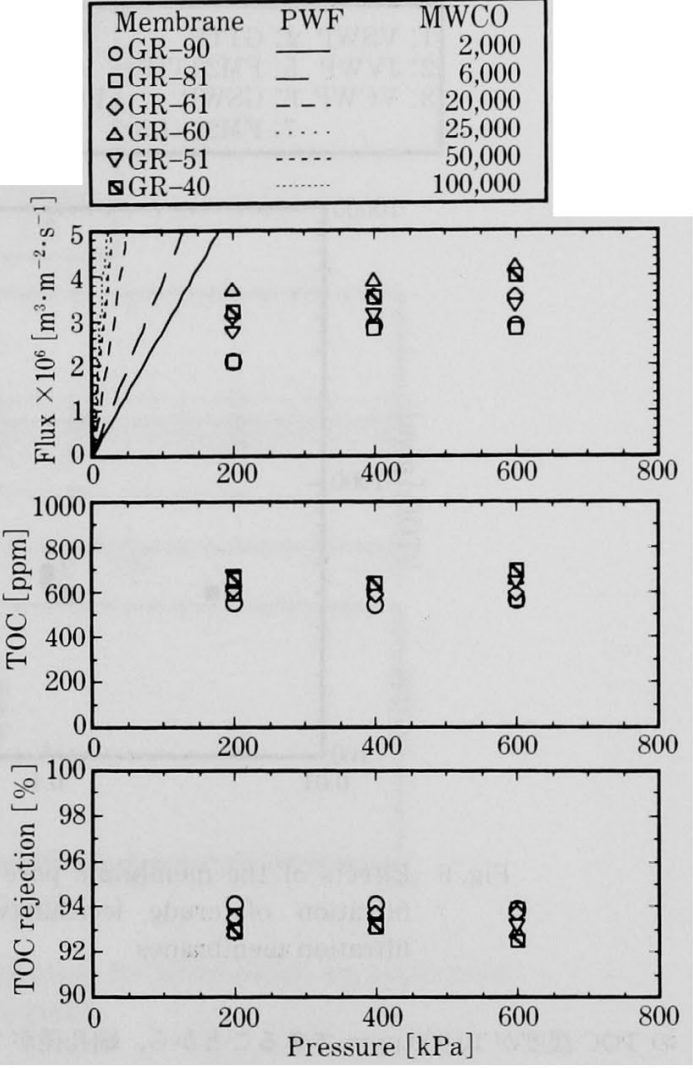

Fig. 5 Effects of the operating pressure on the steady state flux (top), TOC concentration in permeate (middle) and TOC rejection (bottom) in filtration of crude lecithin/water emulsion using ultrafiltration membranes

濃度上 TOC 阻止率を示す．TOC 濃度は $600 \mathrm{ppm}$ 前後， TOC 阻止率は 90〜95\% で，ともに膜による弾いはな く, G 10 膜と同等の值を示している. 限外滤過膜は, G 10 膜より分画分子量が大きく，遊離のリン脂質は阻止し ないが，油滴に関しては完全に阻止していると考えられ る.この結果加ら, 遊離のリン脂質濃度は, 数百 $\mathrm{ppm}$ 程 度であり, その他のリン脂質は, 分子量 100000 以下の ミセルの状態ではほとんど存在せず，それ以上の大きさ の油滴の形成に使われていると考えられる.

\section{3. 精密淲過膜}

図 6 に親水性精密滤過膜を用いて, 粗レシチン/水エ マルションの潗過を行った際の膜細孔径之透過液中の TOC 濃度の関係を示す. 油滴の大きさが $1 \sim 2 \mu \mathrm{m}$, 原液 

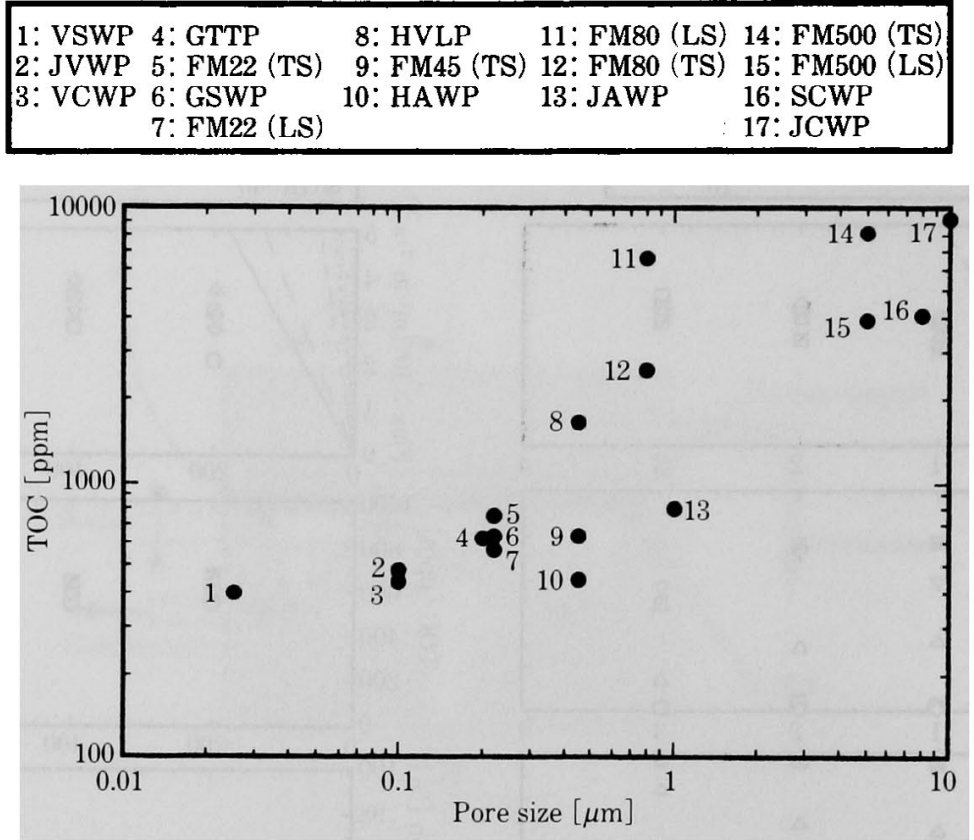

Fig. 6 Effects of the membrane pore size on TOC concentration in permeate in filtration of crude lecithin/water emulsion using hydrophilic microfiltration membranes

の TOC 濃度が 10000 ppm であることから, 細孔径が 1 $\mu \mathrm{m}$ 以上の膜では，油滴はほとんど阻止されないことが 分かる. また逆に，細孔径が $0.22 \mu \mathrm{m}$ 以下の膜では，限 外滤過膜と同等の TOC 濃度となっており，遊離のリン 脂質以外の油分である油滴は阻止していると推察され る.

园 7 に細孔径 $0.22 \mu \mathrm{m}$ 以下の親水性精密滤過膜におけ る透過流束と TOC 阻止率の経時変化を示す. 細孔構造 や材質の違いの影響はなく, いずれの場合む, 逆浸透膜, ナノ滤過膜，限外滤過膜における定常透過流束と同等の 透過流束に滤過初期から達しており, 油滴ヶーク層の形 成が速やかに起こっていることが分かる. TOC 阻止率 も滤過初期から限外滤過膜で得られる值に達しており， 油滴のあれはほとんど生じていないと考えられる.

図 8 に細孔径 $0.45 \mu \mathrm{m}$ 以上の親水性, 疎水性精密滤過 膜における TOC 阻止率上透過流束の時間による変化 （30 300 min）を示す. 細孔径 $0.45 \mu \mathrm{m}$ の膜の場合は, $0.22 \mu \mathrm{m}$ 以下の膜之ほぼ同等の透過流束とわずかに低い TOC 阻止率が得られている.それより孔径の大きい精 密滤過膜の場合は, 膜材質や膜構造の影響が顕著に現れ ている.

\section{（1）非対称構造を持つCA 膜の場合}

粗な面 (LS) を原液側に用いるデプスフィルターとし ての使用の方が, 密な面 (TS) を用いるスクリーンフィ ルターとしての使用より，初期透過流束が高くなってい る.これは，TSを用いた場合は，膜表面における油滴の 付着が直接的な細孔の閉塞と透過流束の隇少をもたらす が，LSを用いた場合は，膜内で油滴が捕捉されても周 りに透過液が流れる空間が確保され, 細孔閉塞が起こり にくいためと考えられる. 時間の経過とともに透過流束 が隇少し, TOC 阻止率が上昇しているのは, 膜内で捕捉 された油滴が透過抵抗の増加に寄与するとと屯に，他の 油滴の透過を妨げるためと考えられる.ただし，FM 500 （TS）の場合は，密な面を原液側に使用しているため， 膜内での油滴の捕捉性が不十分であり，細孔も大きいた め, TOC 阻止率は上昇せず, 細孔の部分的な閉塞による 透過流束の単純な減少に止まっている。

(2) 対称構造を持つ CE 膜の場合

$0.8 \mu \mathrm{m}$ と $5 \mu \mathrm{m}$ の膜では, 透過流束が 0 近くまで減少 した.この原因として,これらの膜は, 油滴と同等, も しくはそれより若干大きく, 膜厚方向に対称に存在して いる細孔を有しておりこのため油滴によって，ほぼ完 


\begin{tabular}{|c|c|c|}
\hline & Pore size $[\mu \mathrm{m}]$ & Material \\
\hline O GSWP & 0.22 & \\
\hline व FM-22 (TS) & 0.22 & $\mathrm{CA}$ \\
\hline - FM-22 (LS) & 0.22 & $\mathrm{CA}$ \\
\hline$\triangle \mathrm{GTTP}$ & 0.20 & PC \\
\hline$\nabla$ VCWP & 0.10 & $\mathrm{CE}$ \\
\hline QJVWP & 0.10 & PTFE \\
\hline 田VSWP & 0.025 & $\mathrm{CE}$ \\
\hline
\end{tabular}
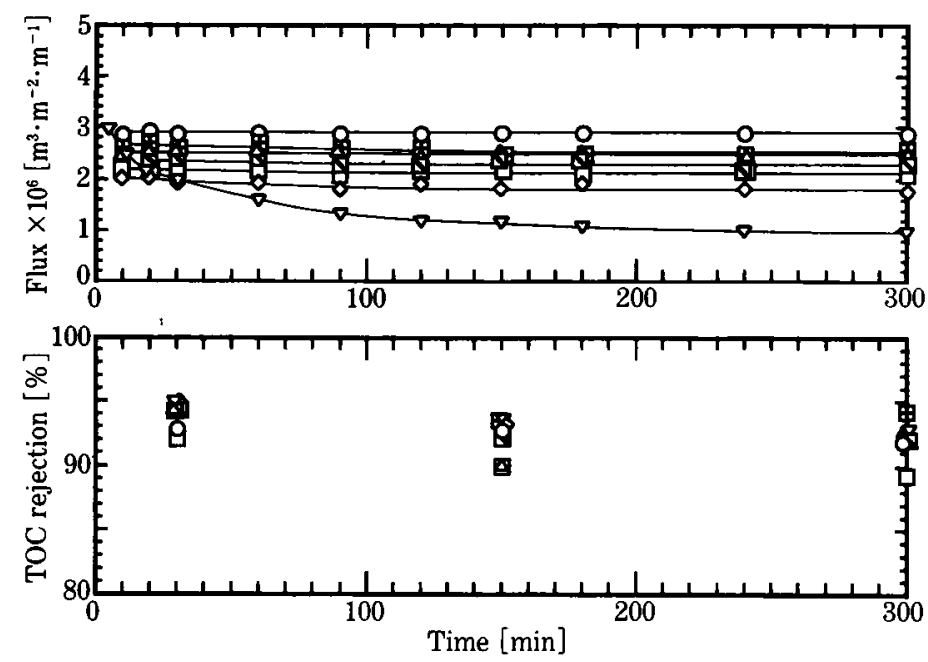

Fig. 7 Time course of the flux and TOC rejection for hydrophilic microfiltration membranes having $0.22 \mu \mathrm{m}$ or smaller pores

全に閉塞されたことが考えられる. $8 \mu \mathrm{m}$ の膜になると 非対称 CA 膜と同様の滤過特性を示している。これは， 細孔が油滴と比較して充分大きくなり，閉塞が起こりに くくなったことを示唆している。ポリメチルメタクリ レート粒子を用いた実験では, 細孔径が粒子径に近いと ころで高い定常透過流束が得られているが(7)，これは緻 密層の薄い非対称膜をデブスフィルターやスクリーン フィルターとして用いた結果である. また，粒子が完全 な固体であり，変形によって細孔が完全に塞がれてしま うことがないことも要因である. 今回のように変形可能 な油滴を㶓過する場合においては，細孔径が油滴の大き さに近い対称膜は，細孔閉塞による透過流束の低下を最 あ引き起こしやすい選択であると云える.

（3）親水性・蹯水性 PTFE 膜の場合

細孔径 $1.0 \mu \mathrm{m}$ の親水性 PTFE 膜の場合は, 非対称 $\mathrm{CA}$ 膜之同様の滤過特性を持つ. 細孔径が油滴の大きさ に近い対称膜であるにも関わらず，透過流束が 0 になら なかったのは, 細孔が細長く', 油滴が細孔内に捕捉され ても間隚が残るためであると推察される. 踈水性 PTFE 膜の場合は，孔径 $1 \mu \mathrm{m}, 5 \mu \mathrm{m}$ の膜で，負の TOC 阻止率
が現れている。これは，O/W エマルションの滤過に疎 水性膜を用いると, 膜内で油滴が蓄皘し，湮縮されて透

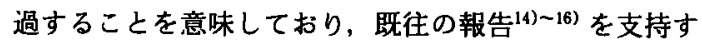
る結果である. 柾水性膜であ細孔径が $10 \mu \mathrm{m}$ となると, 素通りする油滴が増えるため, 非対称 CA 膜と同様の滤 過特性が現れた。

要約

食品産業における含油廃水のモデルとして粗レシチ ン/水エマルションを用い, 種々の膜を用いて, 透過流束 や TOC 阻止性能といった滤過特性の検討を行った．油 滴の大きさより小さな孔径の親水性膜でクロスフロー滤 過を行うことで, 一定の透過流束と TOC 阻止率が得ら れることが明らかになった．これらの膜では，透過流束 は原液流量によって決定されるため，細孔径や材質によ らずほぼ同じ定常透過流束が得られた。TOC阻止性能 は, 塩阻止性能 $30 \%$ のナノ滤過膜, 限外滤過膜, 細孔径 $0.22 \mu \mathrm{m}$ の精密滤過膜まで, ほぼ同じであり，遊離のリ ン脂質の除去には逆浸透膜か $\mathrm{NaCl}$ の阻止率が高く繳密 なナノ滤過膜を用いる必要があることが分かった，逆に 
$\mathrm{TS}=$ tight side, $\mathrm{LS}=$ loose side; $\mathrm{S}=$ symmetric membrane, $\mathrm{AS}=$ asymmetric membrane;

$\mathrm{PL}=$ hydroprilic, $\mathrm{PB}=$ hydrophobic PTFE = polytetrafluoroethylene,

$\mathrm{CE}=$ cellulose mixed ester, $\mathrm{CA}=$ cellulose acetate, $\mathrm{PVDF}=$ polyvinylidene difluoride

\begin{tabular}{|c|c|c|c|c|}
\hline $\begin{array}{l}\text { - LCWP } \\
(\mathrm{S}, \mathrm{PB}, \mathrm{PTFE}, 10.0 \mu \mathrm{m})\end{array}$ & $\begin{array}{l}\text { - JCWP } \\
\text { (S, PL, PTFE, } 10.0 \mu \mathrm{m})\end{array}$ & $\begin{array}{l}\text { - SCWP } \\
(\mathrm{S}, \mathrm{PL}, \mathrm{CE}, 8.0 \mu \mathrm{m})\end{array}$ & $\begin{array}{l}-\mathrm{FM}-500(\mathrm{LS}) \\
(\mathrm{AS}, \mathrm{PL}, \mathrm{CA}, 5.0 \mu \mathrm{m})\end{array}$ & $\begin{array}{l}\text { AM-80 (LS) } \\
\quad(\mathrm{AS}, \mathrm{PL}, \mathrm{CA}, 0.8 \mu \mathrm{m})\end{array}$ \\
\hline $\begin{array}{l}\text { LSWWP } \\
(\mathrm{S}, \mathrm{PB}, \mathrm{PTFE}, 5.0 \mu \mathrm{m})\end{array}$ & & $\begin{array}{l}\text { SMWP } \\
(\mathrm{S}, \mathrm{PL}, \mathrm{CE}, 5.0 \mu \mathrm{m})\end{array}$ & $\begin{array}{l}\text { - FM-500 (TS) } \\
\text { (AS, PL;CA, } 5.0 \mu \mathrm{m})\end{array}$ & $\begin{array}{l}\Delta \mathrm{FM}-80(\mathrm{TS}) \\
\quad(\mathrm{AS}, \mathrm{PL}, \mathrm{CA}, 0.8 \mu \mathrm{m})\end{array}$ \\
\hline $\begin{array}{l}\triangle \mathrm{FAWP} \\
\quad(\mathrm{S}, \mathrm{PB}, \mathrm{PTFE}, 1.0 \mu \mathrm{m})\end{array}$ & $\begin{array}{l}\text { - JAWP } \\
\quad(\mathrm{S}, \mathrm{PL}, \mathrm{PTFE}, 1.0 \mu \mathrm{m})\end{array}$ & $\begin{array}{l}\text { AAWP } \\
(\mathrm{S}, \mathrm{PL}, \mathrm{CE}, 0.8 \mu \mathrm{m})\end{array}$ & & \\
\hline
\end{tabular}

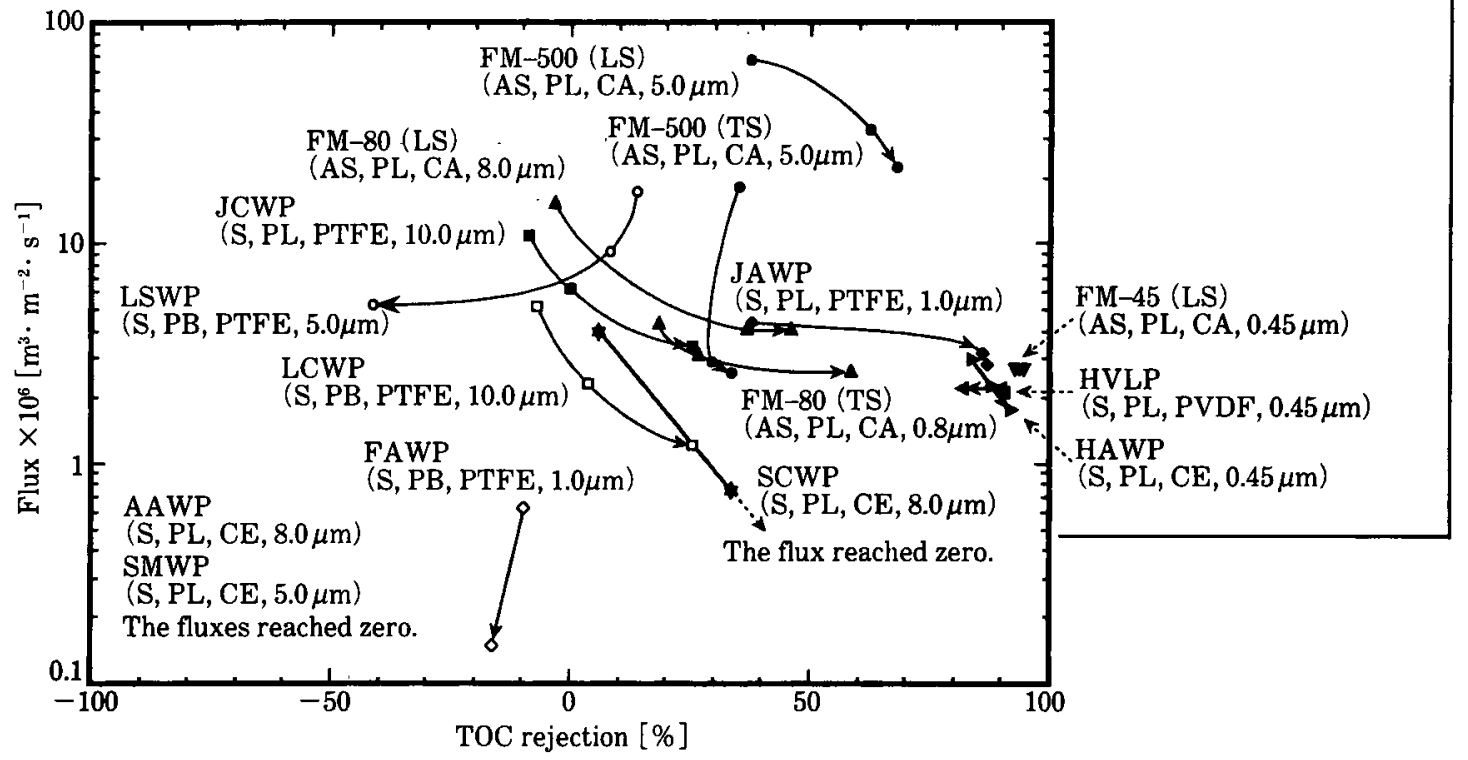

Fig. 8 Relationship between TOC rejection and the flux and TOC rejection with the passage of time for hydrophilic or hydrophobic microfiltration membranes having $0.45 \mu \mathrm{m}$ or larger pores

$90 \%$ 以上のリン脂質やトリグリセリドの除去濃縮を行 うためには, $0.22 \mu \mathrm{m}$ 以下の細孔を持つ精密滤過膜であ れば十分であると云える. 油滴の大きさ以上の細孔径を 持つ精密滤過膜を用いた場合は, 細孔構造や親蹯水性に よって, 様々な特異的な滤過特性が見られた. 非対称膜 はデプスフィルターとしての使用の方が高い透過流束が 得られること、油滴の大きさと同等のスポンジ形状の細 孔を持つ対称膜を用いると透過流束が 0 近くまで減少す ること, 疎水性膜を用いると負の TOC 阻止率が得られ る場合があることが分かった。

\section{文献}

1）全国の水質規制值・平成 7 年, 8 年版, アイピー
`シー水質編集室編（アイピーシー, 東京) p. 78 (1996).

2）水リサイクル技術の親展開, 東レリサーチセン タ一調查研究部門編（東レリサーチセンター, 東 京) p. 83 (1995).

3) Schwering, H., Golisch, P. and KeMP, A. : Plat. Surface Finish., 80, 56 (1993).

4) LAHIERE, R.J. and Goodboy, K.P. : Env. Prog., 12, 86 (1993).

5) Murase, T., OHN, T. and Kamimura, K. : 化学工 学論文集, 22, 120 (1996).

6) Koltuniewicz, A.B., Field, R.W. and ARnot, T. C. : J. Membrane Sci., 102, 193 (1995).

7) Lee, S., Aurelle, Y. and Roques, H. : J. Membrane Sci., 19, 23 (1984). 
8) Belkacem, M., Hadjiev, D. and Aurelle, Y.: Chem. Eng. J., 56, 27 (1995).

9) LOPEZ, R.V., Elmaleh, S. and Ghaffor, N. : $J$. Membrane Sci., 102, 55 (1995).

10) NAKashima, T. and Shimizu, M. : 化学工学論文 集, 15, 645 (1989).

11) NaKashima, T. and Shimizu, M. : 化学工学論文 集, 20, 468 (1994).

12) Kawakatsu, T., Kikuchi, Y. and Nakajima, M. : J. Chem. Eng. Japan, 29, 399 (1996).

13）青井暢之 - 南部宏暢 : 食品用乳化剂, 戸田義郎 角田則昭 - 加藤知治編 (光琳, 東京) p. 67 (1997).

14) Farnand, B.A., SAWATzKy, H. and Poirier, M.A. : Sep. Sci. Technol., 20, 193 (1985).
15) Daiminger, U., Nitsch, W., Plucinski, P. and HoffmanN, S.:J. Membrane Sci., 99, 197 (1995).

16) HlavaceK, M. : J. Membrane Sci., 102, 1 (1995).

17) Kawakatsu, T., Nakao, S. and Kimura, S. : $J$. Membrane Sci., 81, 173 (1993).

18) Kawakatsu, T., Nakao, S. and Kimura, S. : $J$. Chem. Eng. Japan, 26, 656 (1993).

19) Belfort, G., DAvis, R.H. and ZydNEY, A.L. : $J$. Membrane Sci., 96, 1 (1994).

20) Urano, H., Kawakatsu, T., Nabetani, H. and NAKAJIMA, M. : 食科工, 44, 457 (1997).

(平成 10 年 7 月 6 日受付, 平成 10 年 12 月 28 日受理) 